\title{
Pengaruh Pengungkapan Emisi Gas Rumah Kaca terhadap Nilai Perusahaan dengan Biaya Lingkungan sebagai Variabel Moderasi
}

\author{
Miftahul Ulum, Ratno Agriyanto, Warno \\ Universitas Islam Negeri Walisongo Semarang \\ *Correspondence address: warno@walisongo.ac.id
}

\section{㟒勒}

ISSN: 1979-4703 (p)

ISSN: 2527-9726(e)

Keywords:

Disclosure of Greenhouse

Gas, Emissions,

Environmental Costs,

Company Value

\begin{abstract}
A B S T R A C T
Global warming is caused by an increase in greenhouse gas emissions in the atmosphere, so companies must take responsibility for this through activities to reduce emissions. The purpose of this study is to examine whether environmental costs can moderate the disclosure of greenhouse gas emissions against firm value. This research is a type of quantitative analysis. The sampling technique used purposive sampling. The collecting data through literature study, documentation and secondary data from the Indonesia Stock Exchange 2014-2018. The data analysis technique used the WarpPls 4.0 analysis. They are testing the data using the inner model and outer model methods. This study indicates that GHG emission disclosure has a negative and significant effect on firm value. Environmental costs also have a negative and significant impact on firm value. Meanwbile, ecological prices are not able to moderate the impact of GHG emission disclosures on company value.
\end{abstract}

\section{A B S T R A K}

Pemanasan global di sebabkan oleh kenaikan emisi gas rumah kaca di atmosfer sehingga perusahaan harus turut serta bertanggung jawab terhadap hal tersebut melalui aktivitas untuk mengurangi emisi. Tujuan studi ini yaitu untuk menguji apakah biaya lingkungan mampu memoderasi pengungkapan emisi gas rumah kaca terhadap nilai perusahaan. Penelitian ini merupakan jenis penelitian kuantitatif. Teknik pengambilan sampel menggunakan purposive sampling. Metode pengumpulan data dengan cara studi pustaka, dokumentasi dan data sekunder dari Bursa Efek Indonesia tahun 2014-2018. Teknik analisis data menggunakan analisis WarpPls 4.0. Pengujian data menggunakan teknik inner model, dan outer model. Hasil penelitian ini menunjukkan bahwa pengungkapan emisi GRK berpengaruh negatif dan signifikan terhadap nilai perusahaan. Begitupun dengan biaya lingkungan yang memiliki pengaruh negatif dan signifikan terhadap nilai perusahaan. Sedangkan biaya lingkungan tidak mampu memoderasi pengaruhnya pengungkapan emisi GRK terhadap nilai perusahaan. 


\section{Pendahuluan}

Pemanasan global terjadi hampir diseluruh belahan dunia tidak terkecuali Indonesia. Meningkatnya suhu udara di atmosfer di sebabkan oleh aktifitas manusia yang kurang ramah lingkungan. Pemanasan global di sebabkan oleh kenaikan emisi gas rumah kaca di atmosfer seperti karbondioksida (CO2), metana (CH4), dinitrooksida (N2O), dan chlorofluorocarbons (CFC). Emisi gas rumah kaca (GRK) merupakan kandungan emisi yang disebabkan oleh gas-gas karbon di atmosfer sehingga mendorong pemanasan global. Penanggulangan emisi GRK oleh negara-negara di dunia telah dibentuk dengan persetujuan yang disebut Protocol Kyoto. Indonesia juga mengeluarkan Perpres No. 61 tahun 2011 mengenai penurunan emisi GRK dan No. 71 tentang inventarisasi gas rumah kaca berskala nasional. Menurut Purbaet al. (2017) pada tahun 2014 total emisi gas rumah kaca Indonesia mencapai 1.808 juta ton $\mathrm{CO}^{2}$ pertahun dari 2000-2013. PT Pertamina tercatat pada posisi ke-35 penyumbang emisi GRK global. Untuk itu pemerintah membentuk target penurunan emisi GRK di Indonesia sebesar 29\%-41\% pada tahun 2030. Tetapi kenyataannya pengungkapan emisi GRK di Indonesia masih pada tingkat pelaporan secara suka rela. Sehingga beberapa perusahaan penyumbang emisi dalam jumlah besar, tetapi hanya sedikit yang mau melaporkannya.

Penelitiahan Anggraeni (2015), menyatakan bahwa pengungkapan emisi gas rumah kaca memiliki pengaruh positif pada nilai perusahaan. Penelitian Wijaya (2019) mengungkapkan bahwa volume emisi karbon memiliki pengaruh secara positif namun tidak signifikan terhadap nilai perusahaan. Tetapi Berthelot \& Magnan (2017) dalam penelitiannya menyatakan tingkat emisi karbon mempunyai dampak negatif dan signifikan terhadap nilai perusahaan. Penelitian Chithambo (2013) mengungkapkan tentang kualitas pengungkapan emisi GRK mempunyai keterkaitan dengan manfaat dan biaya lingkungan. Pengungkapan biaya lingkungan dari setiap perusahaan berbeda-beda tergantung informasi dan skala lingkup perusahaannya. Perusahaan terkadang mengabaikan biaya lingkungan sebab biaya lingkungan hanya dianggap sebagai penunjang kegiatan operasioanl bukan produksi. Arisandi dan Frisko (2011) mengungkapkan bahwa biaya lingkungan dapat menaikkan nilai pemegang saham sebab termasuk bentuk CSR perusahaan kepada lingkungan. Menurut penelitihan Albertini (2013), menyatakan bahwa terdapat pengaruh positif dari pengelolaan biaya lingkungan yang tepat terhadap nilai perusahaan. Tetapi fitriani (2013) memberikan gambaran mengenai biaya lingkungan yang tidak memiliki pengaruh terhadap nilai perusahaan. Begitu juga dengan penelitihan praditya (2018) biaya lingkungan tidak dapat memoderasi profitabilitas terhadap nilai perusahaan. Penelitian Vieni (2017) juga manyatakan bahwa environmnetal cost memiliki pengaruh tidak signifikan pada nilai perusahaan. Dalam AlQuran kegiatan sosial terhadap lingkungan termuat dalam surah Al-A'raf ayat 56 yang menyeruh agar tidak melakukan kerusakan di bumi.

Berdasarkan latar belakang diatas adanya berbagai gap dalam riset sebelumnya maka tuujuan studi ini adalah untuk mengetahui pengaruh pengungkapan pengungkapan emisi GRK terhadap nilai perusahaan, pengaruh biaya lingkungan terhadap nilai 
perusahaan, dan pengaruh pengungkapan emisi GRK terhadap nilai perusahaan dengan biaya lingkungan sebagai variable moderasi.

\section{Tinjauan Pustaka}

\section{Teori Legitimasi}

Legitimasi merupakan suatu teori yang mendasari motivasi entitas secara suka rela mengungkapkan laporan pertanggung jawaban sosial dan lingkungan. Teori ini juga menjelaskan bahwa perusahaan termasuk dalam unit bagi kehidupan sosial. Teori legitimasi dilakukan dalam rangka mendapatkan legitimasi dari masyarakat guna keberlangsungan jangka panjang perusahaan. Masyarakat akan mengakui peranan perusahaan apabila terdapat hubungan sosial dengan lingkungan. Teori legitimasi dilakukan dalam rangka mendapatkan legitimasi dari masyarakat guna keberlangsungan jangka panjang perusahaan. Dalam hal ini informasi mengenai lingkungan menjadi upaya mendapatkan legitimasi perusahaan (Richatul Jannah and Dul Muid, 2014). Informasi pengungkapan emisi GRK dan biaya lingkungan perusahaan dapat dijadikan sebagai acuan timbal balik sosial. Peranan perusahaan dalam pelaporan yang akurat akan menambah nilai suatu entitas. Dengan begitu legitimasi publik akan terbentuk sehingga menambah minat pasar kepada perusahaan.

\section{Corporate Social Responsibility}

Rika dan Ishlahuddin (2008) mengungkapkan bahwa (CSR) Corporate Social Responsibility merupakan suatu bentuk tanggung jawab entitas dalam berbakti terhadap pembangunan ekonomi berkelanjutan. CSR diatur dalam Undang-Undang No. 23 Tahun 1997 tentang Pengelolaan Lingkungan Hidup. Undang-undang tersebut mengatur bagi setiap individu untuk menjaga serta menanggulangi kerusakan lingkungan. CSR merupakan kontribusi perusahaan dalam pembangunan sosial, lingkungan, dan ekonomi. CSR perusahaan diinformasikan dalam laporan tahunan (Mubarok, 2019). Informasi CSR berupa kepedulian perusahaan terhadap lingkungan. Pengungkapan emisi GRK dan biaya lingkungan termasuk bentuk tanggung jawab sosial perusahaan untuk kesejahteraan lingkungan. Hal ini menyebabkan pandangan baik dari investor untuk perusahaan

\section{Green Accounting}

Bell dan Lehman (1999) mengungkapkan green accounting atau akuntansi lingkungan adalah catatan laporan keuangan yang berisi biaya-biaya terkait aktifitas perusahaan terdadap lingkungan. Green accounting merupakan kegiatan memasukkan biaya lingkungan dalam proses pencatatan akuntansi pada perusahaan. Akuntansi lingkungan dapat digunakan sebagai rencana untuk melestarikan lingkungan. Akuntansi ini digunakan sebagai alat untuk mengevaluasi dampak kerusakan lingkungan atau disebut dengan biaya 


\section{At-Taqaddum}

Vol. 12 No. 2 (2020) 155-168

konservasi. Green accounting merupakan kegiatan memasukkan biaya lingkungan dalam proses pencatatan akuntansi pada perusahaan. Biaya lingkungan merupakan efek yang ditimbulkan dari operasional yang berkaitan dengan lingkungan baik bersifat moneter maupun tidak (Eric Gunawan, 2012). Perusahaan perlu mengeluarkan biaya untuk tujuan kelestarian lingkungan. Biaya ini termasuk dalam tanggung jawab sosial perusahaan terhadap lingkungan.

\section{Gas Rumah Kaca}

Riebeek (2010) mengungkapkan bahwa gas rumah kaca (GRK) adalah gas dari pemanasan global yang ada dalam atmosfer sehingga mendorong terbentuknya efek rumah kaca. Beberapa peneliti menggunakan istilah carbon disclosure atau pengungkapan karbon sebab termasuk dalam gas-gas yang mendorong terjadinya global warming. Emisi GRK termuat dalam surah Al-A'raf ayat 56 yang melarang berbuat kerusakan pada lingkungan. Berdasarkan Perpres No. 61 emis GRK adalah lepasnya gas-gas ke atmosfer yang menimbulkan pemanasan global pada waktu dan kondisi tertentu. Emisi GRK semakin bertambahnya waktu terus meningkat sebab aktifitas penggunaan energi fosil, kebakaran hutan, perubahan tata guna lahan, dan operasional perusahaan yang merusak lingkungan.

\section{Nilai Perusahaan}

Nilai perusahaan menurut Mardiyanto (2009) merupakan nilai saat ini berdasarkan alur kas masuk untuk masa mendatang yang dihasilkan oleh perusahaan. Nilai perusahaan juga disebut sebagai tingkat pencapaian perusahaan yang tercermin dalam harga pasar saham perusahaan. Beaver (dalam Muhammad Khafid 2002) mengungkapkan apabila dalam laporan tahunan mengungkapkan harga saham yang tinggi mencerminkan nilai perusahaan yang baik. Nilai perusahaan tercermin dalam surah An-Nisa ayat : 29 menyeruh untuk melakukan perniagaan dengan prinsip saling ridha. Investor berinvestasi atau membeli perusahaan melihat nilai perusahaan yaitu pada nilai pasar atau harga saham. Nilai pasar dijadikan sebagai indikator dalam menentukan nilai perusahaan. Fama (1978) menjelaskan nilai perusahaan bisa diketahui berdasarkan harga saham perusahaan. Harga tersebut juga menunjukkan penilaian investor terhadap perusahaan. Harga saham juga menunjukkan penilaian investor terhadap perusahaan. Semakin naiknya harga saham tentu mengakibatkan bertambahnya nilai perusahaan.

\section{Biaya Lingkungan}

Susenohaji (2003) menjelaskan biaya lingkungan sebagai pengorbanan yang dilakukan oleh perusahaan terkait dengan timbulnya kerusakan lingkungan serta perlindungannya. Biaya lingkungan juga disebut sebagai Environmental Quality Cost. Informasi biaya lingkungan dalam perusahaan masuk sebagai akuntansi lingkungan. Akuntansi lingkungan merupakan praktek memasukkan biaya lingkungan ke dalam 
laporan tahunan perusahaan. Biaya lingkungan tercermin dalam surah Ar-Ruum ayat 41 memberikan peringatan kepada manusia tentang akibat yang timbul apabila lingkungan telah dirusak.

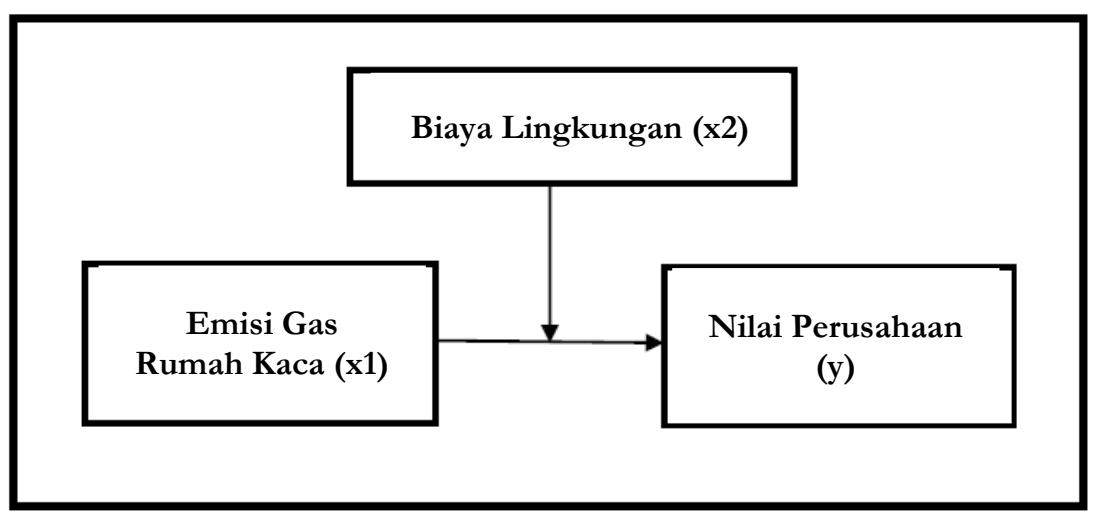

Gambar 2.1. Kerangka Pemikiran Teoritik

\section{Pengembangan Hipotesis}

Transparansi laporan keuangan ke publik dapat dijadikan acuan pihak eksternal dalam mengetahui kondisi perusahaan. Penelitihan Anggraeni (2015) telah menghasilkan pengaruh positif mengenai pegungkapan emisi GRK terhadap nilai perusahaan. Hal tersebut berarti managemen berhasil mengungkapkan emisi GRK. Sehingga investor beranggapan bahwa managemen telah berperan dalam tanggung jawab sosial terhadap lingkungan. Penelitihan Anggraeni (2015) telah menghasilkan pengaruh positif mengenai pegungkapan emisi GRK terhadap nilai perusahaan. Hal tersebut berarti managemen berhasil mengungkapkan emisi GRK. Sehingga investor beranggapan bahwa managemen telah berperan dalam tanggung jawab sosial terhadap lingkungan. Melalui informasi pengungkapan emisi GRK dalam laporan keuangan maka akan memahami kebijakan, nilai dan motif perusahaan dalam menaggulangi dampaknya bagi lingkungan. hal tersebut akan memunculkan nilai tersendiri pada perusahaan.

Hal tersebut bertolak belakang dari hasil penelitian Hsu dan Wang (2013) tentang pengungkapan pencadangan biaya lingkungan tidak begitu penting bagi perusahaan sebab investor akan khawatir mengenai perbandingan biaya dengan return. Apabila biaya yang dikorbankan perusahaan lebih tinggi dari return maka informasi pengungkapan emisi GRK di anggap mahal. Begitu juga dengan laporan yang sifatnya negatif seperti perubahan cuaca dalam annual report yang membawakan citra buruk terhadap perusahaan. Untuk itu hipotesis pertama yaitu :

\section{H1: Pengungkapan emisi GRK berpengaruh positif terhadap nilai perusahaan.}

Biaya lingkungan perusahaan termasuk dalam kegiatan Sustainibility Report atau CSR yang termuat pada laporan tahunan. Tanggung jawab sosial perusahaan dapat 


\section{At-Taqaddum}

Vol. 12 No. 2 (2020) 155-168

mendorong timbulnya legitimasi sosial terhadap perusahaan. Perusahaan yang melaksanakan biaya sosial tentunya akan menarik minat investor. Begitu juga dengan harga saham, tentunya akan terpengaruhi sejalan dengan kewajiban perusahaan dalam melaksanakan biaya sosial. Berdasarkan penelitian Buana (2017) menjelaskan bahwa data sampel penelitian tidak berhasil membuktikan environmnetal cost berpengaruh signifikan terhadap nilai perusahaan. Begitu pula Fitriani (2013) mengungkapkan bahwa biaya lingkungan tidak berpengaruh pada nilai perusahaan. Tetapi penelitian Albertini (2013) menghasilkan hubungan positif antara pengelolaan biaya lingkungan yang baik terhadap profitabilitas dan nilai perusahaan. Maka dari itu hipotesis kedua yang di pakai yaitu :

\section{H2: Biaya lingkungan berpengaruh secara signifikan terhadap nilai perusahaan.}

Peneliti berusaha memasukkan variabel biaya lingkungan untuk memoderasi pengungkapan emisi GRK dengan nilai perusahaan. Menurut Hermawan dan Mafulah (2014) posisi biaya lingkungan mampu menguatkan hubungan positif antara profitabilitas dengan nilai perusahaan. Tetapi penelitian Wardhana (2017) menjelaskan biaya lingkungan tidak mampu memoderasi pengaruh profitabilitas terhadap nilai perusahaan. Pengungkapan biaya lingkungan memang memiliki keterkaitan dengan nilai perusahaan. Maka dari itu hipotesis yang ketiga adalah :

\section{H3: Biaya lingkungan dapat memoderasi pengaruhnya antara pengungkapan emisi GRK terhadap nilai perusahaan.}

\section{Metode Penelitian}

Penelitian ini menggunakan pendekatan kuantitatif. Sumber data menggunakan data sekunder, yaitu data literatur berupa buku, situs website resmi perusahaan, jurnal penelitian, dan skripsi penelitian sebelumnya. Data diambil dari laporan keuangan tahunan perusahaan energi yang terdaftar di BEI tahun 2018 berdasarkan situs web resmi Indonesian Stock Excange (IDX). Pemilihan sampling memakai metode purposive sampling (Megarani et al., 2019). Adapun kriteria purposive sampling dalam penelitian ini adalah :

a. Perusahaan sektor energi yang terdaftar di BEI tahun 2018.

b. Perusahaan yang mempublikasikan laporan keuangan tahunan pada tahun 20142018.

c. Perusahaan yang menyajikan laporan emisi GRK, dan biaya CSR tahun 20142018.

\section{Variabel Penelitian Dan Pengukuran Variabel Independen}

Variabel independen dalam penelitian ini yaitu pengungkapan emisi GRK. Indikator menggunakan sistem checklis yang dipakai Choi et al berdasarkan informasi dari Carbon Disclosure Project. Pengukuran variabel ini menggunakan rasio PEGRK dengan 
rumus:

$$
\text { PEGRK }=\frac{\text { jumlah item yang diungkapkan }}{\text { jumlah seluruh item pengungkapan }} x 100 \%
$$

\section{Variabel Moderasi}

Variabel moderasi dalam penelitian ini adalah biaya lingkungan. Fitriani (2013) mengukur biaya lingkungan (BL) dengan cara membandingkan biaya kegiatan CSR dengan laba bersih. Adapun rumus biaya lingkungan (BL) adalah:

$$
B L=\frac{\text { Biaya } C S R}{\text { Laba Bersih }}
$$

\section{Variabel Dependen}

Nilai perusahaan dijadikan sebagai variabel dependen dalam penelitian ini. Price Book V alue (PBV) merupakan alat ukur yang dipakai pada penelitian ini. Rumus dari PBV adalah:

$$
\text { Price Book Value (PBV) }=\frac{\text { Harga Pasar Saham }}{\text { Nilai Buku }}
$$

\section{Analisis Data}

Penelitian ini memakai teknik analisis Partial Least Square (PLS) dengan software WarpPLS 4.0. Pengujian PLS dapat memprediksi dan membangun suatu teori, menganalisis sampel berukuran kecil, dan model fit. PLS mampu menganalisis keterkaitan non-linear antara variabel serta mengoreksi nilai koefisien jalur. Analisis PLS dapat menggambarkan nilai koefisien jalur dan P-value yang berguna dalam teknik moderasi variabel secara langsung. Disamping itu WarpPls juga dapat memberikan pengaruh secara tidak langsung (indirect effect) sehingga tidak perlu menghitung manual. Pengujian analisis data dalam PLS yaitu outer model, inner model, dan hipotesis.

\section{Hasil dan Pembahasan}

Tabel 2. Analisis Deskriptif

\begin{tabular}{lccccc}
\hline & N & MIN & MAX & MEAN & S.D \\
\hline PEGRK & 35 & 0,11 & 0,83 & 0,35 & 0,2 \\
BL & 35 & 0,01 & 55 & 4,1 & 12,9 \\
PBV & 35 & 0,3 & 3,9 & 1,2 & 0,9 \\
\hline
\end{tabular}

PEGRK adalah penghitungan rasio untuk mengukur pengungkapan emisi GRK. Hasil rata-rata PEGRK sebesar 0,35 atau 35\%. Nilai rata-rata tertinggi PEGRK adalah 
PT. Perusahaan Gas Negara (Persero) Tbk. yaitu sebesar 0,79 atau 79\%. Dan nilai ratarata terendah yaitu PT. Darma Henwa Tbk. sebesar 0,17 atau 17\%. PEGRK adalah penghitungan rasio untuk mengukur pengungkapan emisi GRK. Semakin besar nilai dari PEGRK menunjukkan bahwa tanggung jawab perusahaan dalam mengungkapkan emisi GRK semakin baik.

PBV merupakan seberapa besar kemampuan entitas dalam menentukan nilai perusahaan yang berhubungan dengan modal investasi. PBV merupakan seberapa besar kemampuan entitas dalam menentukan nilai perusahaan yang berhubungan dengan modal investasi. Nilai rata-rata PBV secara keseluruhan sebesar 1,2. Nilai rata-rata PBV tertinggi yaitu PT. Bukit Asam Tbk. sebesar 2,4. Nilai rata-rata terendah yaitu PT. Darma Henwa Tbk. sebesar 0,3. Biaya lingkungan (BL) adalah penghitungan rasio untuk mengetahui pengorbanan perusahaan pada kelestarian lingkungan. BL dapat diukur dengan membandingkan biaya CSR dengan laba bersih perusahaan. Semakin besar nilai BL maka tingkat pengorbanan perusahaan terhadap kelestarian lingkungan akan semakin tinggi. Nilai rata-rata BL secara keseluruhan sebesar 4,06. Nilai rata-rata BL tertinggi diperoleh oleh PT. Darma Henwa Tbk. sebesar 27,88. Nilai rata-rata BL terendah adalah PT. Rukun Raharja Tbk. sebesar 0,01.

\section{Pengaruh Pengungkapan Emisi Gas Rumah Kaca terhadap Nilai Perusahaan}

Hasil analisis data menyatakan pengungkapan emisi GRK berpengaruh negatif dan signifikan terhadap nilai perusahaan. Hal tersebut berarti semakin lengkap pengungkapan emisi GRK maka nilai perusahaan akan menurun. Turunnya harga saham di pasar terjadi sebab investor menganggap bahwa semakin besar pengungkapan emisi GRK menyebabkan meningkatnya beban tanggung jawab sosial perusahaan. Berdasarkan penelitian Hsu dan Wang (2013) bahwa pengungkapan emisi GRK akan menimbulkan biaya sehingga pasar akan khawatir terhadap pembengkakan anggaran. Begitu juga dengan perbandingan biaya dan return, apabila jumlah biaya lebih besar dari pada return maka pengungkapan emisi gas rumah kaca di anggap mahal. Disamping itu pasar cenderung tidak menyukai laporan yang bersifat negatif seperti perubahan cuaca dari perusahaan. Karena hal tersebut akan membawa citra buruk bagi perusahaan sehingga akan menurunnya harga saham.

Li et al. (2013) juga mengungkapkan bahwa implementasi perencanaan reduksi emisi GRK berpengaruh negatif dan signifikan terhadap nilai buku aset serta arus kas. Konar dan Cohen (2001) juga menyatakan dalam penelitiannya mengenai dampak negatif bagi perusahaan yang mempublikasikan emisi kimia terhadap nilai perusahaan. Emisi karbon dianggap sebagai beban oleh investor. Apabila pada laporan tahunan menpublikasikan emisi karbon secara lengkap, tentu investor akan menganggap bahwa beban dan tanggung jawab entitas akan tinggi. Pengungkapan informasi tersebut dapat merugikan dan menurunkan reputasi perusahaan. Hal tersebut dapat mengancam keberlangsungan operasional perusahaan. Sehingga nilai perusahaan juga ikut terancam. Pernyataan tersebut sesuai dengan penelitian Mc Combs dan Shaw (1972). Hal tersebut sejalan dengan teori legitimasi yang menyatakan bahwa pengungkapan emisi gas rumah 
kaca secara sukarela akan membawakan citra perusahaan dimata investor. Transparansi laporan tahunan akan menyebabkan legitimasi publik terhadap perusahaan. Pasar dapat menentukan tingkat keberhasilan perusahaan dalam laporan tahunannya yang berakibat terbentuknya legitimasi sosial. Informasi yang relevan akan membantu publik dalam mengetahui kondisi perusahaan dan meminimalkan potensi resiko dimasa mendatang

\section{Pengaruh Biaya Lingkungan terhadap Nilai Perusahaan}

Hasil penelitian menunjukkan biaya lingkungan berpengaruh negatif dan signifikan terhadap nilai perusahaan. Hal tersebut berarti semakin tinggi biaya lingkungan yang dikeluarkan maka nilai perusahaan akan menurun. Sebab biaya lingkungan akan menjadi beban bagi perusahaan. Penambahan biaya secara langsung dapat mengurangi penerimaan laba dan harta dari pemegang saham. Beban yang tinggi dapat menyebabkan menurunnya nilai perusahaan. Pasar juga akan lebih tertarik kepada perusahaan yang memiliki biaya yang relative rendah. Buana dan Nuzultga (2017) mengungkapkan dalam penelitiannya bahwa biaya lingkungan menghasilkan profit yang tidak pasti bagi perusahaan. Pasar menilai biaya lingkungan sebagai sesuatu beban operasional. Semakin tinggi beban maka nilai perusahaan juga akan merosot. Babalola (2012) juga mengungkapkan bahwa dana yang dipakai dalam investasi CSR berpengaruh negatif terhadap profit perusahaan. Hal tersebut terjadi sebab pengeluaran untuk kegiatan CSR kurang mendapatkan kontribusi ekonomi kepada perushaan. Biaya lingkungan termasuk bentuk legitimasi perusahaan kepada lingkungan. Lingkungan dan masyarakat akan mengakui CSR apabila perusahaan mengeluarekan biaya lingkungan. Meskipun tidak mampu menarik minat investor tetapi biaya lingkungan harus tetap diutamakan bagi perusahaan sebab termasuk dalam tanggung jawab sosial terhadap sekitar (Awwaliyah et al., 2019).

\section{Pengaruh Biaya Lingkungan dalam Memoderasi Pengungkapan Emisi Gas Rumah Kaca dengan Nilai Perusahaan}

Hasil penelitian mengungkapkan bahwa biaya lingkungan berpengaruh negatif dan tidak signifikan. Biaya lingkungan tidak mampu memoderasi hubungan pengaruh antara pengungkapan emisi gas rumah kaca dengan nilai perusahaan. Hal tersebut disebabkan oleh peraturan pengungkapan emisi GRK masih suka rela. Perusahaan sektor energi yang menyumbangkan emisi GRK tinggi namun belum sepenuhnya diungkapkan dengan alasan pembengkakan anggaran. Begitupun dengan biaya lingkungan dijadikan sebagai kewajiban perusahaan yang termasuk dalam beban. Apabila beban meningkat maka nilai perusahaan akan menurun. Biaya lingkungan tidak mampu berpengaruh terhadap nilai perusahaan apabila pengungkapan emisi gas rumah kaca rendah. Sebab biaya lingkungan dapat timbul dari pengungkapan emisi GRK. Sejalan dengan penelitian Fitriani (2013) bahwa dana yang dikeluarkan untuk lingkungan tidak memiliki pengaruh terhadap nilai perusahaan. Hal tersebut karena biaya lingkungan kurang memiliki konsekuensi ekonomi. Walaupun biaya lingkungan telah dikeluarkan tetapi tidak membawakan manfaat secara 


\section{At-Taqaddum}

Vol. 12 No. 2 (2020) 155-168

langsung. Penelitian ini juga didukung oleh Wardhana (2017) walaupun memiliki perbedaan variabel yaitu biaya lingkungan tidak mampu memoderasi pengaruhnya antara profitabilitas dengan nilai perusahaan. Dalam penelitian ini biaya lingkungan lebih berpengaruh kepada nilai perusahaan. Sehingga hasil penelitian ini dapat dikatakan sebagai prediktor moderasi. Dimana biaya lingkungan memiliki hubungan terhadap nilai perusahaan tetapi tidak mampu menjadi variabel moderasi.

\section{Kesimpulan}

Berdasarkan hasil penelitian dan analisis data dapat ditarik kesimpulan bahwa ada pengaruh pengungkapan emisi gas rumah kaca terhadap nilai perusahaan dengan biaya lingkungan sebagai variabel moderasi (Studi Kasus pada Perusahaan Sektor Energi yang Terdaftar Di Bursa Efek Indonesia Tahun 2014-2018). Variable pengungkapan emisi gas rumah kaca (GRK) berpengaruh negatif dan signifikan terhadap nilai perusahaan, dibuktikan dengan nilai koefesien sebesar $-0,33$ dan $P$-value $<0,01$ atau $<0,05$ dan variabel biaya lingkungan berpengaruh negative dan signifikan terhadap nilai perusahaan, dibuktikan dengan nilai koefesien sebesar $-0,38$ dan $P$-value $<0,02$ atau $<0,05$ serta varaiabel biaya lingkungan tidak mampu memoderasi hubungan pengungkapan emisi gas rumah kaca (GRK) dengan nilai perusahaan, dibuktikan dengan nilai koefesien sebesar 0,03 dan $P$-value $=0,37$ atau $>0,05$.

\section{Daftar Pustaka}

Abdullah. Tafsir Ibnu Katsir Jilid 2. Bogor: Pustaka Imam Asy-syafi'i, 2004. . Tafsir Ibnu Katsir Jilid 3. Bogor: Pustaka Imam Asy-syafi'i, 2004. . Tafsir Ibnu Katsir Jilid 6. Bogor: Pustaka Imam Asy-syafi'i, 2004.

Agriyanto, Ratno. "Analisis Perataan Laba dan Pengaruhnya Terhadap Reaksi Pasar dan Risiko Investasi pada Perusahaan Publik di Indonesia." Universitas Diponegoro, 2006.

Agriyanto, R. "Model Rekayasa Perilaku Menggunakan Informasi Akuntansi Berbasis Akrual Pada Organisasi Pemerintah." Jurnal Akuntansi Dan Keuangan Indonesia 15, no. 1. 2018.

Agriyanto, R. "Redefining Objecktive of Islamic Banking : Stakeholders Perspective In Indonesia." Economica 6, no. 2. 2015.

Awwaliyah, N. F., Agriyanto, R., \& Farida, D. N. (2019). The effect of regional original income and balance funding on regional government financial performance. Journal of Islamic Accounting and Finance Research, 1(1), 25. https://doi.org/10.21580/jiafr.2019.1.1.3745 
Agriyanto, Ratno, Dessy Noor Farida, and Rizki. MK. "The Effect of Sustainability Report and Profitabilityon Company Value : Evidence from Indonesian Sharia Shares." Economica : Jurnal Ekonomi Islam 10, no. 1. 2019.

Anggraeni, Dian Yuni. "Pengungkapan Emisi GRK, Kinerja Lingkungan, Dan Nilai Perusahaan." Jurnal Akuntansi Dan Kenangan Indonesia 12, no. 2. 2015.

Ary Wirajaya, Ayu. "Pengaruh Struktur Modal, Profitabilitas Dan Ukuran Perusahaan Pada Nilai Perusahaan." E-Jurnal Akuntansi 4, no. 2. 2013.

Azisah, Ika Nur. "Pengaruh Latar Belakang Pendidikan Non Akuntansi Terhadap Kualitas Auditor Dengan Pengalaman Audit Sebagai Variabel Moderasi Pada Perwakilan BPKP Provinsi Sulawesi Selatan.” Jurnal Fondasi 1. 2013.

Buana, Vieni Angelita, and Nila Firdausi Nuzultga. "Pengaruh Environmental Cost Terhadap Profitabilitas Dan Nilai Perusahaan (Studi Pada Perusahaan Kimia First Section Yang Terdaftar Di Japan Exchange Group Perode 2013 - 2015)." Jurnal Administrasi Bisnis (JAB) 50, no. 1. 2017.

Camilia, Ica. "Pengaruh Kinerja Lingkungan Dan Biaya Lingkungan Terhadap Kinerja Keuangan Perusahaan Manufaktur." Sekolah Tinggi Ilmu Ekonomi Perbanas Surabaya, 2016.

Dahlan, Muhammad Auliya'a. "Pengaruh Return On Asset (ROA) Dan Debt To Equity Ratio (DER) Terhadap Harga Saham Dengan Kebijakan Dividen Sebagai Variabel Intervening." UIN Alauddin Makassar, 2018.

Dessy Noor, Farida, and Warno. "Akuntansi Lingkungan: Kajian Penerapan Dalam Perspektif Islam ( Studi Kasus Pada Perusahaan Yang Tercatat Di Jakarta Islamic Index ( JII ))." Shariah Paper Accounting FEB UMS, 2015.

Directorate General of Climate Change. "2018 Statistics,” 2019.

Franciska, Regina Mariana, Jullie J Sondakh, and Victorina Z Tirayoh. "Analisis Penerapan Akuntansi Biaya Lingkungan." Jurnal Riset Akuntansi Going Concern 14, no. 1. 2019.

Gunawan, Eric. "Tinjauan Teoritis Biaya Lingkungan Terhadap Kualitas Produk Dan Konsekuensinya Terhadap Keunggulan Kompetitif Perusahaan.” Jurnal Ilmiah Mabasiswa Akuntansi 1, no. 4. 2012.

Haribowo, Ignatius Novianto. "Pengaruh Pengumuman Likuidasi Bank Terhadap Minat Menarik Uang Dari Bank.” Modus 29, no. 1. 2017.

idx.co.id. "PT Bursa Efek Indonesia.” Idx, 2018. https://www.idx.co.id/.

Jannah, Richatul, and Dul Muid. "Analisis Faktor-Faktor Yang Mempengaruhi Carbon Emission Disclosure Pada Perusahaan Di Indonesia." Diponegoro Journal of Accounting 3, no. 2. 2014.

Khoiriyah, Nurul. "Pengaruh Ukuran Perusahaan Dan Profitabilitas Terhadap Nilai 
Perusahaan Dengan Kebijakan Deviden Sebagai Ariabel Pemoderasi." UIN Maulana Malik Ibrahim Malang, 2018.

Kusumadilaga, Rimba. "Pengaruh Corporate Social Responsibility Terhadap Nilai Perusahaan Dengan Profitabilitas Sebagai Variabel Moderating." Universitas Diponegoro, 2010.

Kusumaningtias, Rohmawati. "Green Accounting, Mengapa Dan Bagaimana?” Proceeding Seminar Nasional Dan Call for Papers Sancall, 2013.

Majid, Rizqi Abdul. "Faktor-Faktor Yang Mempengaruhi Gas Rumah Kaca Pada Perusahaan Di Indonesia.” Universitas Diponegoro, 2015.

Mubarok, F. K. (2019). Analisis Implementasi Corporate Social Responsibility Pada Perusahaan Berlabel Syariah Di Bursa Efek Indonesia. Media Trend, 14(2), 154-165. https://doi.org/10.21107/mediatrend.v14i2.4539

Mulyani, Nita Sri. "Analisis Penerapan Akuntansi Biaya Lingkungan Pada Pabrik Gondorukem Dan Terpentin (Pgt)." Universitas Jember, 2013.

Musthofa, Ujang Hanief. "Menggagas Pengembangan Akuntansi Syariah Pendekatan Integratif-Interkonektif." LAIN Raden Intan Lampung, 2001.

Nilasari, Fitri. "Analisis Penerapan Akuntansi Lingkungan Terhadap Pengelolaan Limbah." Artikel Ilmiah Mabasiswa, no. 1. 2014.

Nurizqi, Agung. "Pengaruh Biaya Corporate Social Responsibility Terhadap Profitabilitas Perusahaan Partisipan Indonesia Sustainability Reporting Award." Institut Pertanian Bogor, 2017.

Nurlela, Rika. "Pengaruh Corporate Social Responsibility Terhadap Nilai Perusahaan Dengan Prosentase Kepemilikan Manajemen Sebagai Variabel Moderating." Artikel Ilmiah, 2006.

Permanasari, Wien Ika. "Pengaruh Kepemilikan Manajemen, Kepemilikan Institusional, Dan Corporate Social Responsibility Terhadap Nilai Perusahaan." Universitas Diponegoro, 2010.

Prafitri, Anistia, and Zulaikha Zulaikha. "Analisis Pengungkapan Emisi Gas Rumah Kaca Anistia Prafitri Zulaikha Departemen Akuntansi Fakultas Ekonomika Dan Bisnis Universitas Diponegoro." Jurnal Akuntansi \& Auditing 13, no. 2. 2016.

Pratiwi, Wahyu Mega. "Akuntansi Lingkungan Sebagai Strategi Pengelolaan Dan Pengungkapan Tanggung Jawab Lingkungan Pada Perusahaan Manufaktur." Universitas Negeri Surabaya, 2012.

Pratysto, Tangguh, Ingrid Panjaitan, and Redaktur Wau. "Pajak Karbon Dioksida Transportasi Dan Target Emisi Gas Rumah Kaca Indonesia." Media Akuntansi Perpajakan 2, no. 2. 2017.

Rahayu, Maryati, and Bida Sari. "Faktor-Faktor Yang Mempengaruhi Nilai Perusahaan." 
Ikraith-Humaniora 2, no. 74. 2018.

Rimawati, Ayu Mey. "Pengaruh Pengetahuan Pajak Dan Pengetahuan Zakat Terhadap Kepatuhan Wajib Pajak Dengan Sikap Sebagai Variabel Moderasi.” Institut Agama Islam Negeri Surakarta, 2019.

Sahamok.com. "Saham OK_ Investasi Saham Indonesia Lebih Realistis," 2020.

Setiawan, Temy. "Penerapan Akuntansi Manajemen Lingkungan Pada Dua Puluh Lima Perusahaan Yang Terdaftar Di Indeks Sri Kehati 2013.” Jurnal Akuntansi 9, no. 2. 2018.

Singgih, Moses L. "Pengukuran Dampak Lingkungan Menggunakan Environmental Management Accounting (EMA).” Institut Teknologi Sepulub November, 2007.

Suroyya, Zizza Elya. "Pengaruh Karakteristik Perusahaan Terhadap Pengungkapan Emisi Gas Rumah Kaca Pada Perusahaan Di Indonesia.” Universitas Diponegoro, 2018.

Suryani, Rohman. "Faktor Penentu Atas Luas Emisi Gas Rumah Kaca Di Indonesia." Institut Agama Islam Negeri Surakarta, 2019.

Tbk., PT. Adaro Energy. “Laporan Tahunan 2018,” 2018.

Tbk., PT. Bukit Asam. "Laporan Keuangan 2018,” 2018.

Tbk., PT. Darma Henwa. "Laporan Tahunan 2018,” 2018.

Tbk., PT. Elnusa. “Laporan Tahunan 2018,” 2018.

Tbk., PT. Indo Tambangraya Megah. “Laporan Tahunan 2018,” 2018.

Tbk., PT. Perusahaan Gas Negara (Persero). “Laporan Tahunan 2018,” 2018.

Tbk., PT. Rukun Raharja. “Laporan Tahunan 2018,” 2018.

Wardhana, Praditya Kusuma. "Pengaruh Biaya Lingkungan Dan Kinerja Lingkungan Dalam Memoderasi Pengaruh Profitabilitas Terhadap Nilai Perusahaan." Universitas Negeri Surabaya, 2017.

Wibawa, Shierine Wangsa. "71 Persen Gas Rumah Kaca Global Ternyata Berasal Dari $100 \quad$ Produsen." Kompas.Com, 2017. https://sains.kompas.com/read/2017/07/12/080800823/71.persen.gas.rumah.ka ca.global.ternyata.berasal.dari.100.produsen.

Wijaya, Naura Saniyna. "Pengaruh Volume Emisi Karbon Dan Sistem Manajemen Lingkungan Terhadap Nilai Perusahaan Dengan Pengungkapan Emisi Karbon Sebagai Variabel Intervening." Universitas Diponegoro, 2019. 